\title{
Emerging theories of value and commodity in design education and professional practice. Intoduction
}

\section{Faerm, Steven [ver currículum del autor, docente de la Facultad de Diseño y Comunicación]}

\section{Abstract:}

The successful advancement of design and attendant industries will require a shift, from developing tactical methods of design into those that are strategic and truly meet consumers' increasingly complex needs. One fundamental method is evaluating how consumers' concepts of value evolves over time. Value is typically created by factors such as supply and demand, rarity, age, trends (zeitgeist), materials, and/or the brand itself. Yet, these traditional forms of value shift when situated in world where there is an over-abundance of design; for the majority of consumers, all of their basic physical needs are met, and even over-met. Thus, designers must attract their consumers not merely with their products' physical attributes, but with intangible values that strategically target and fulfill their consumers' increasingly complex emotional needs. What is the new "value" of design? In design education and professional practice, how will the ways we assess value and commodity change? It is with this need to question and expand the necessary discourse around new theories of value and commodity in design and design education that the Parsons authors present their papers.

Key words:

design - value - commodity - consumerism - entrepreneurship - design education - design process - cultural identity - craft - advertising - marketplace.

(*) Associate Professor of Fashion at Parsons School of Design (Program Director, BFA Fashion Design, 20072011). A Parsons alumnus (94') and Designer of the Year Nominee, he began teaching in 1998 while working for 
such designers as Marc Jacobs and Donna Karan. He has been recognized for his teaching by winning "The University Distinguished Teaching Award" and The BFA Fashion Design Program's "Teaching Excellence Award".

What is "value"? In design education and professional practice, have the ways we assess value and commodity evolved? How does this shift inform the future of design education and design practice? The design industries and their attendant marketplaces have undergone radical, accelerated transformations. The mass-obsession with design, which is driving the over-abundance of low-cost "high" design, combined with excessive consumerism, the hyper-globalized nature of the world today, and the Earth's rapidly depleting resources are just some of the factors requiring designers to reimagine the concept of "value" in their work. Value is typically created by factors such as supply and demand, rarity, age, trends (zeitgeist), materials, and/or the brand itself. If an object is in high demanded, the supply drops and value rises; conversely, low demand increases supply and decreases price. Not everything rare has value, but when rarity and high demand combine, value escalates. A design's age can also affect value; historical or nostalgic artifacts, as well as the latest and most technologically advanced designs, can create high demand and, thus, value. Materials used in the design can also offer tangible forms of value that can be universally recognized, while the very brand (or maker) of the object can offer value through associated prestige. But how does "value" shift when there is an over-abundance of design? Moreover, how does this overabundance of product affect user/consumer behaviors and perceptions of design? How can the designer and the design industry respond? These questions are salient when contextualized within a design landscape where, for example, there are nearly 330 fashion presentations during New York Fashion week and there are over 150 fashion weeks around the world. Today's consumers are inundated with "stuff"; for the majority, their basic needs are met, and even over-met. Using Maslow's Hierarchy of Needs as a premise, once these basic necessities are met, today's first world-consumers climb higher up the pyramid to its apex where they actively seek out meaningful life experiences and self-actualization. Thus, designers must attract their consumers not merely with their products' physical attributes, but with intangible values that strategically target and fulfill their consumers' increasingly complex emotional needs. Understanding current definitions of "value" and "commodity" within the design context enables both design practitioners and educators to successfully reimagine and redefine how we relate to design, the ways systems are imagined and conceived, and the types of positive change we wish to engender on local/global levels. Our past values, the ways these have evolved in various cultures, and how we can successfully scaffold our future elicit key questions in and around what the new commodities, and the values that accrue to them, will be. It is with this desire to question the shifting values and commodities within design, industry, and design education that we present this year's journal. Authors were asked to consider what new forms of commodity and attendant value will emerge in the future. In addition, they were asked to consider how designers and/or design educators can prepare for such change via pragmatic or theoretical means. Our Parsons authors address a wide variety of themes that include design education, design objects and systems, sustainability, design trends and social integration, commercial media, economics, globalization/ localization, social justice, and design practice/industry

The articles

Aaron Fry, Rhea Alexander, and Samar Ladhib

in The School of Design Strategies (SDS) begin by discussing the rise of design following the 2008-09 recession in the US. The authors assert the recession "was a watershed moment in the development of business practices" that spawned a new generation of US companies and re-invigorated established businesses. These new and 
invigorated entrepreneurs share attributes with designers including adaptability, initiative, risk and failure tolerance, ability to think-and-work across disciplines, creativity, and a problem-solving mindset. The new roles of the designer and entrepreneur -and possible methods of working with design higher education- are considered in the post-recession design industry landscape. Parsons' Entrepreneurs Lab (ELab) -an incubator-design school hybrid-is presented by the authors as one possible scenario for how this new dynamic may foster. These scenarios combining entrepreneurship with design higher education offer new forms of business and academic values since, as the authors assert, "design education finds itself at a moment of great challenge (as well as great opportunity), and, as with business leaders -design educators risk squandering the opportunity that their own 'crisis' (in their case, about the purpose of a design education) affords them-for reconceiving what design is, and does, in a 21 st Century economy."

Steven Faerm in The School of Fashion (SoF) presents an inquiry into why and how our understanding of "value" and "commodity" in design education and professional practice must be rethought. Faerm posits that designers and their attendant industries must reposition the conventional focus of what to design to how to design. This necessary shift is due to several factors including contemporary culture's obsession with design, the knowledgebased economy, and an overabundant/oversaturated marketplace. It is within this overabundant/oversaturated marketplace that consumers' basic needs are met; consumers are increasingly driven by their search for meaning and emotional fulfillment through design. To succeed and sustain customer loyalty, designers must shift their focus from creating mere artifact (the "what" of design) to developing highly complex narratives and design processes (the "how" of design) that will create new forms of perceived -and emotional- value. The author concludes by proposing a new paradigm: the "DesignerAs-Social Scientist" who -through advanced studies and research methods- is able to strategically target consumers' increasingly complex and personalized psychographic profiles. Anya Kurennaya in The School of Art, Design, History, and Theory (ADHT) questions how creative impulses and lived realities interact and inform one another throughout the design process. Kurennaya examines the mechanics of the design process by observing and recording the design processes of three graduate-level fashion design students, and incorporates modern linguistic theory as the starting point for her investigation. Kurennaya argues that the "fashion design process is open to the kind of improvisation inherent in any ongoing lived experience, the final product representing a culmination of the ideas, desires, decisions, obstacles, and other circumstances shaping its production." Thus, like language and conversation, the design process is complex, full of disruption, diversion, reformulation, and rearticulation. The author asserts that if we can recognize the design process' nonlinear and experimental nature, we have the potential to recognize that design has the potential to inform us about society and give us the tools to actively change it. A new value as "social change agent" is then fostered. Laura Beltran-Rubio, alumna of the MA Fashion Studies program in The School of Art, Design, History, and Theory (ADHT) presents a paper in a time when Columbian nationals "are engaging in the re-construction of a national identity, especially through cultural production". The power exerted by fashion design in forming cultural identity is due in part to its highly visualized presence, and its ability to cross cultures while possessing relevancy. Beltran-Rubio studies the work of two Columbian fashion designers Johanna Ortiz and Pepa Pombo- and the unique ways they reimagine Columbian culture in their work for both the local and global markets. The author asserts that Ortiz's utilization of Columbia's national flower and Pombo's interpretations of indigenous communities' textiles contribute to deconstructing Columbia's negative stereotypes of armed conflict and drug cartels. By reinterpreting these cultural inspirations in the designers' own aesthetics, Beltran-Rubio posits that a new image of Columbia -both for export and for the Columbian people- emerges to promote a new national identity. This new form of added value that surpasses the mere physical object 
addresses both community and country. Aaron Fry, Gabriele Goretti, Samar Ladhib, Elisabetta

Cianfanelli, and Carol Overby representing The School of Design Strategies (SDS) and The University of Florence in Italy, present our fifth paper. Like Beltran-Rubio, Fry et al. consider the value adopted by design due to its production in a specific location and/or by local artisans. The authors "discuss the trend toward consumption of artisanal products in developed economy markets, and query whether artisanal value lies in the 'branding' of products as artisanal or in the 'saper fare' or intrinsic traditional craftsmanship." The authors focus on the Tuscan region and provide examples in which added value of innovation in Global Value Chains (GVC) contrasts with the value of traditional, localized, and historic crafts practices. The authors argue that GVC-enabled processes have relegated highly-skilled Tuscan artisans to subservient roles as suppliers of labor to global luxury designers and brand managers. A proposal for "advanced craft" comprised of customizable and agile methods enabled through digital production techniques is made; this can combine with the Italian saper fare to place skilled artisans at the center of the process of thought-in-action, thus empowering craftsmen and designers to share information as cocreators of design. Our sixth and final paper is presented by Thomas Werner in The School of Arts, Media, and Technology (AMT) and Steven Faerm in The School of Fashion (SoF). In this paper, Werner and Faerm discuss the ways in which international corporations have increasingly created advertising campaigns that aim to create social change at local and global levels. As the global marketplace evolves and consumer demographics shift, corporations are creating visual narratives that can cross cultural boundaries, engage the growing sociallyminded consumer groups, and positively impact communities. The authors present and analyze select advertising campaigns that employ compelling visual and written narratives that address social issues for positive cultural change. The authors then discuss how these campaigns have been used in international and culturally diverse classroom settings (e.g. The United Nations Education First (UN/EF) Summer School, The State Hermitage Museum in Saint Petersburg, Russia, and Parsons School of Design, New York) to foster student peer-to-peer dialog, understanding, and acceptance of topics such as human rights. The authors believe that "the success of these advertising campaigns, then, is no longer restricted to their content, but to their abilities to target the audience the organization would like to inform, instruct, or persuade. These abilities are particularly meaningful and impactful when the campaigns successfully target audience members who can actually affect change." A new form of value emerges not solely on the revenue earned, but increasingly on the positive social change achieved.

\section{Parsons School of Design}

As a leader in art and design education, Parsons School of Design in New York City is considering the future of the art and design education and practice through ongoing conversations and evolving academic philosophies. Parsons contains five Schools: The School of Fashion (SoF); The School of Constructed Environments (SCE); The School of Art, Design, History, and Theory (ADHT); The School of Arts, Media, and Technology (AMT); and The School of Design Strategies (SDS). Within each School, graduate and undergraduate programs house disciplines that relate to one another. For example, in AMT, the programs of Fine Arts and Illustration are contained; SCE offers graduate and undergraduate degrees in Architecture and Interior Design; and SoF offers programs in Fashion Design and Fashion Marketing. While these Schools offer students their own areas of disciplinary study, broader philosophies in art and design education are influencing programs' academic frameworks and curricula in order to contextualize each student's area of study; the importance for this breadth and depth- has even led to the creation of a graduate-level interdisciplinary program and undergraduate course pathways that allow students to experience multiple Schools and the broader New School University offerings, 
thus supporting the belief that "design thinking" and cross-disciplinary partnerships may reshape design education and practice. I would like to sincerely thank Aaron Fry who served as Assistant Editor on this journal. His deep commitment to this year's publication, from its nascent stage to its final delivery, was tremendous. I'm truly indebted to his unbridled passion and commitment.

\section{Resumen:}

El exitoso avance del diseño y sus industrias relacionadas requerirán de la implementación de un cambio que permita pasar del desarrollo de metodos tácticos de diseño a métodos estratégicos que respondan efectivamente a las crecientes y complejas necesidades de los consumidores. Uno de los métodos fundamentales consiste en evaluar cómo el concepto de "valor" que tienen los consumidores evoluciona a lo largo del tiempo. Ese "valor" está creado generalmente por factores como la oferta y demanda, la diferenciación, la edad, las tendencias, los materiales y/o la marca en sí misma. Parsons presentan sus trabajos.

\section{Palabras clave:}

diseño - valor - productos básicos - consumismo - emprendedorismo - educación en diseño - procesos de diseño - identidad cultural - artesanía - publicidad - Mercado.

\section{Resumo:}

O bem sucesso avanço do design e suas indústrias relacionadas exigirão a implementação de uma mudança que permita passar do desenvolvimento de métodos tácticos de design a métodos estratégicos que respondam efetivamente às crescentes e complexas necessidades dos consumidores. Um dos métodos fundamentais consiste em avaliar como o conceito de valor que têm os consumidores evolui ao longo do tempo. Esse valor está criado geralmente por fatores como a oferta e a demanda, a diferenciação, a idade, as tendências, os materiais e/ou a marca em se mesma. Contudo, estas formas tradicionais de valor mudam quando se manifestam num mundo onde superabunda o design; onde para a maioria dos consumidores as necessidades físicas básicas estão satisfeitas, e, às vezes, supersatisfeitas. Portanto, os designers devem atrair aos seus consumidores não somente com os atributos físicos de seus produtos, senão com aqueles valores intangíveis que estrategicamente dirigem-se a satisfazer suas necessidades emocionais cada vez mais complexas. Qual é o novo valor do design? Como mudarão as maneiras nas quais atribuímos valor no ensino do designe e na prática profissional? Os autores de Parsons apresentam seus trabalhos com a necessidade de questionar e ampliar o discurso ao redor das novas teorias do valor no design e no ensino do design.

\section{Palavras chave:}

design - valor - produtos básicos - consumismo - empreendedorismo - educação em design - processos do design - identidade cultural - artesanato - publicidade - mercado.

Emerging theories of value and commodity in design education and professional practice. Intoduction fue publicado de la página 169 a página174 en Cuadernos del Centro de Estudios de Diseño y Comunicación № 64 